This is the authors version of "Delegation of Judicial Power in Abbasid Egypt", in Berkel M.L.M. van, Buskens L.P.H.M., Sijpesteijn P.M. (eds.), Legal Documents as Sources for the History of Muslim Societies: Studies in Honour of Rudolph Peters, Leiden: Brill, 2017.

Please cite from the published version only, DOI: 10.1163/9789004343733_005

\title{
Delegation of judicial power in Abbasid Egypt ${ }^{1}$
}

\section{Petra M. Sijpesteijn}

The papyrus edited in this article and which forms the starting point of the discussion in it is typical in its sort: insignificant in appearance, but of hugely important historical meaning when placed in its proper context. Only partially preserved, so that its contents and even its genre remain unknown, and without an archeological context to place it firmly in a specific chronology and geography, the papyrus contains only a couple of lines. Typically too is that this apparently insignificant artifact preserved from a distant past offers on closer scrutiny important new information on the office of the $q \bar{a} d \bar{l}$ and his representatives in Abbasid Egypt, more specifically as a result of the administrative reforms introduced after the fourth fitna.

Even the rich documentary record of Egypt, attests only very few documents referring to $q \bar{a} d \bar{l} \bar{s}$ from the pre-Fatimid period so far. This dearth of information on the $q \bar{a} d \bar{l}$ starkly contrasts the amount of legal documents - contracts of loan and sale, debt acknowledgements, marriage contracts and the like - which although small in the first Islamic century still greatly outnumbers that of documents referring to the judge's court. ${ }^{2}$ This scarce presence of the $q \bar{a} d \bar{l}$ in the documentary record has been related to the slow development of the Islamic legal court system especially outside the garrison cities of Fustat and Alexandria. ${ }^{3}$ Every new document that attests a $q \bar{a} d \underline{l}$ is thus a welcome addition to our understanding of the functioning of the judge's office. When, as in our case, the documents can be related to narrative sources, their historiographical value even increases as they allow us to examine historical accounts in tandem with documentary sources. Connecting the papyrus to discussions in our literary sources from Egypt and elsewhere in the Muslim Empire it even enlightens more general historical questions about the character and perception of judicial power in this period.

\footnotetext{
${ }^{1}$ This publication is part of the project "The Formation of Islam: The view from Below" funded by the European Research Council (2009-2015). I would also like to thank the Andrew W. Mellon Foundation which funded my research stay at the Department of Papyri of the Austrian National Library (2013-2014) where I worked on this text. In preparation of this article I benefited from expertise of many colleagues. I would like to acknowledge especially Sobhi Bouderbala, Jelle Bruning, and Mathieu Tillier. Any remaining mistakes are, of course, my own.

${ }^{2}$ To get an impression of the number of early Arabic legal documents, see the database of the project "Islamic Law Materialized” (http://cald.irht.cnrs.fr/php/ilm.php) under the direction of Christian Müller.

${ }^{3}$ Mathieu Tillier, "Du pagarque au cadi: ruptures et continuités dans l'administration judiciaire de la HauteÉgypte (Ier-IIIe/Vie-IXe siècle),” Médiévales 64 (2013): 19-36.
} 
This is the authors version of "Delegation of Judicial Power in Abbasid Egypt", in Berkel M.L.M. van, Buskens L.P.H.M., Sijpesteijn P.M. (eds.), Legal Documents as Sources for the History of Muslim Societies: Studies in Honour of Rudolph Peters, Leiden: Brill, 2017.

Please cite from the published version only, DOI: 10.1163/9789004343733_005

Grateful for Ruud's sincere academic interest in legal documents for their own sake and as sources to illuminate historical and legal historical questions, this article is a tribute to his contagious enthusiasm for and academic achievements in the practical expressions of Islamic law.

\section{Introduction}

Sometime between 10 Rajab 212 AH (October 5827 CE) and Ramaḍān 214 AH (2

November-1 December 829 CE) Hasan b. Ya'qūb produced an official document in which he identified himself as "representative (khalīfa) in the Fayyūm of Yahyā b. Sa '̄id who is the representative of the judge ( $q \bar{a} \underline{\imath} \bar{l}$ ) 'Isāa b. al-Munkadir." 'Isā b. al-Munkadir is the well-known chief judge of Fustat who held office in the first half of the ninth century. ${ }^{4}$ Yahyā b. Sa $\overline{1} \mathrm{i}$ and Hasan b. Ya qūb are not otherwise known from the sources. The practice of appointing lower judicial officers as deputies of the highest representative in the provincial capital is known from Egypt and other areas in the Muslim empire at this time as discussed in narrative sources. ${ }^{5}$ How these lower officials expressed their association with higher forces, and thereby their relation with, degree of dependence on and measure of accountability towards the central authorities, however, is not. By examining the terminology used in this papyrus as well as anecdotal material from the narrative sources, this paper will discuss the nature of the delegation of judicial power from the top of the judicial hierarchy and the claim to authority that was exercised through it from the lower offices in the province. Attention will also be placed on the professionalization of the judiciary in Egypt at this time and the degree to which these offices and power structures formed a (legal) bureaucracy.

Before delving further into contextualizing the text of the papyrus, we should take a closer look at what it actually says.

\footnotetext{
${ }^{4}$ See especially the exhaustive discussion of literary sources in the footnotes to Mathieu Tillier's translation of al-Kindī’s biography of 'Īsā b. al-Munkadir (Tillier 2012, 204-215). 'İsā b. al-Munkadir appears in two other papyri from Egypt. A published debt acknowledgement (P.Marchands V/I 19.1) dated 214/829 mentions the $q \bar{a} d \bar{l}$ 'Īsā b. al-Munkadir (as identified in a corrected reading by Sobhi Bouderbala). An unpublished papyrus found at Istabl Antar in Fustat to be published by Sobhi Bouderbala equally mentions the judge in an official context. I would like to thank Sobhi Bouderbala for referring me to these two documents.

${ }^{5}$ See below, the paragraph "Delegation and legitimization."
} 
This is the authors version of "Delegation of Judicial Power in Abbasid Egypt”, in Berkel M.L.M. van, Buskens L.P.H.M., Sijpesteijn P.M. (eds.), Legal Documents as Sources for the History of Muslim Societies: Studies in Honour of Rudolph Peters, Leiden: Brill, 2017.

Please cite from the published version only, DOI: 10.1163/9789004343733_005

\section{Edition and discussion of the text}

Currently preserved in the Papyrus Collection of the Austrian National Library under the inventory number AP 2090, the conditions of acquisition of this papyrus are not known beyond it having been purchased in Egypt. It has a light brown colour and the original cutting lines are preserved on the top and right sides. While the fibres on the left side are somewhat frayed, the remaining lines are complete on that side. There are some smaller holes in the papyrus due to worm holes and wear and tear. There is one diacritical dot written (1. 4 bi) and perhaps one other one (l. 1 bi). The text is written in a relatively practiced, fluid hand albeit not very carefully executed (see also the smudge that partially covers the basmala in line 1) in black ink with a thin pen parallel to the fibres. On the verso the top of the letters of one word written in monumental script are preserved written in dark ink as well as traces of letters written in a smaller hand with black ink. The traces of the monumental writing on the verso belong to a text that was written first on the papyrus, confirmed by the fact that that text is written perpendicular to the fibres. ${ }^{6}$ The smaller writing on verso might be connected to the writing on recto. The verso might contain part of the address of the text on recto or some other text unrelated to the text on the recto.

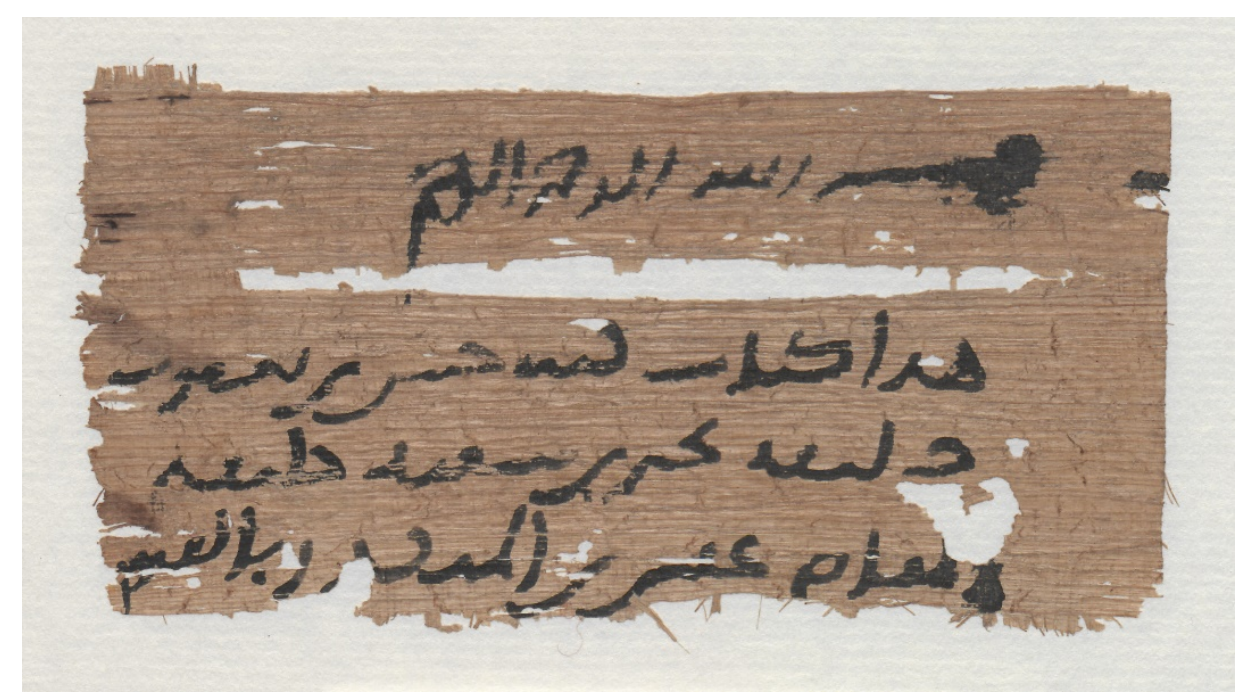

\footnotetext{
${ }^{6}$ Continuing Byzantine practice, papyri in the Arab period were generally written transversa charta, with secondary texts being written parallel to the fibres. See my “Arabic Papyri and Islamic Egypt,” in The Oxford Handbook of Papyrology, edited by R. S. Bagnall, 452-472 (Oxford: Oxford University Press, 2009) for a discussion of the writing direction on papyri in the Arab period.
} 
This is the authors version of "Delegation of Judicial Power in Abbasid Egypt", in Berkel M.L.M. van, Buskens L.P.H.M., Sijpesteijn P.M. (eds.), Legal Documents as Sources for the History of Muslim Societies: Studies in Honour of Rudolph Peters, Leiden: Brill, 2017.

Please cite from the published version only, DOI: 10.1163/9789004343733_005

P.Vindob. A.P. 2090 front. Source: Österreichischen Nationalbibliothek, Papyrussammlung und Papyrusmuseum.

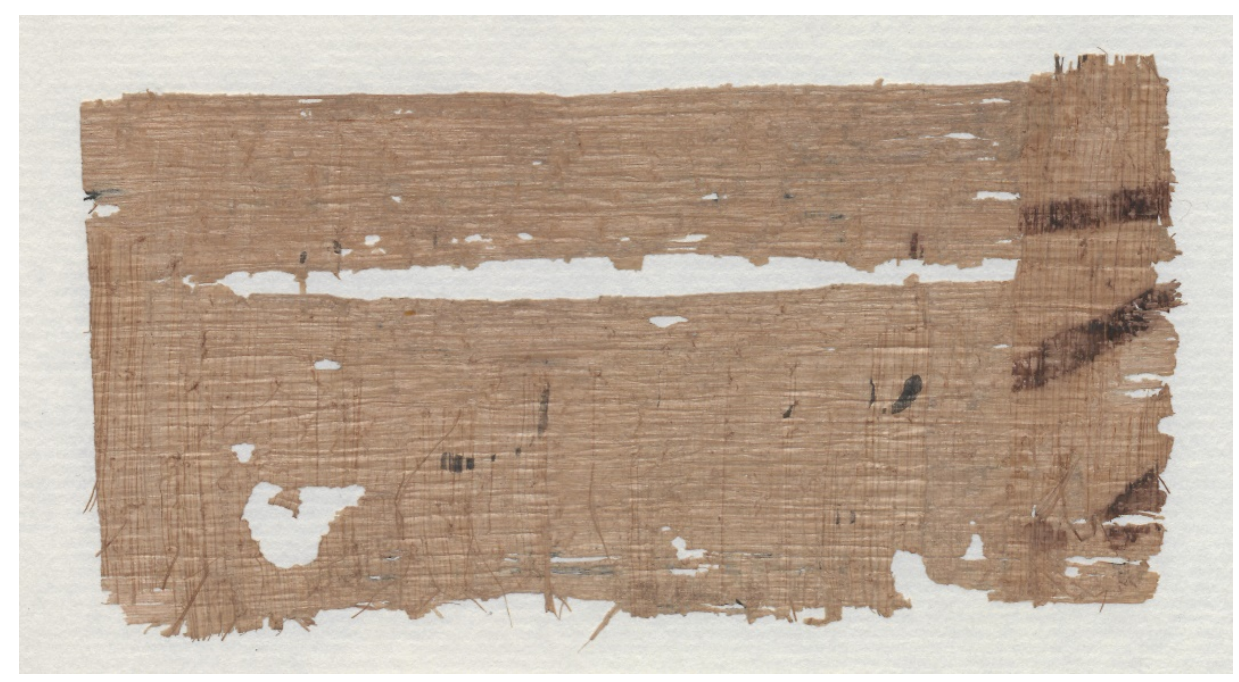

P.Vindob. A.P. 2090 back. Source: Österreichischen Nationalbibliothek, Papyrussammlung und Papyrusmuseum.

AP $2090^{7}$

$5.5 \times 11 \mathrm{~cm}$

Text

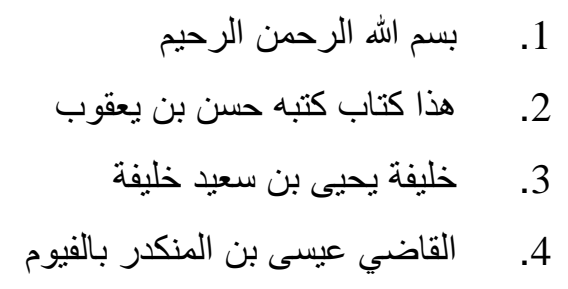

Diacritical dots:

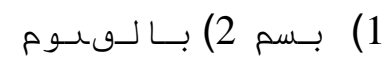

Translation

1. In the name of God, the Merciful, the Compassionate.

2. This is a document, written by Hasan ibn Ya'qūb,

3. representative of Yahyā ibn Sa ${ }^{\prime} \bar{i} d$, representative

\footnotetext{
${ }^{7}$ I would like to thank Bernhard Palme and Claudia Kreuzsaler of the Department of Papyri at the Austrian National Library for permission to publish this papyrus.
} 
This is the authors version of "Delegation of Judicial Power in Abbasid Egypt", in Berkel M.L.M. van, Buskens L.P.H.M., Sijpesteijn P.M. (eds.), Legal Documents as Sources for the History of Muslim Societies: Studies in Honour of Rudolph Peters, Leiden: Brill, 2017.

Please cite from the published version only, DOI: 10.1163/9789004343733_005

4. of the judge 'Îsā ibn al-Munkadir in the Fayyūm

\section{Commentary}

1. A smudge has partially obscured the basmala. A dot under the line seems to belong to the $b \bar{a}$ ' of $b i$.

2. Hasan ibn Ya'qūb is not known from the literary and documentary records.

3. Yahyā ibn Sa ${ }^{1} \overline{1} d$ is not attested in the documentary or literary sources. In the first word on the line, khalīfa, the $k h \bar{a}$ ' is separated from the lām.

4. 'İsā ibn al-Munkadir is the well-known chief judge who was in office from 10 Rajab 212 AH (October 5827 CE) to Ramaḍān 214 AH (2 November-1 December $829 \mathrm{CE})$ in Fustat. $^{8}$

\section{Competition between the centre and the province}

The papyrus under discussion dates from the mid $-9^{\text {th }}$ century and reflects the new power relations and administrative structures in place after the take-over by the Abbasid general 'Abd Allāh b. Țāhir (d. 230/844). New arrangements between the earliest Arab settlers, Egyptians and new Arab, Turkish and Persian immigrants as well as the centralizing measures imposed on the administration by the Abbasid authorities from Baghdad as represented by their appointees in Egypt, are reflected in the affiliations with which the person who produced the papyrus identified himself.

The administrative organisation within Egypt as reflected in the text exhibits also larger empire-wide developments and concerns. The impact of the relation between the province and the caliphal court with Egypt's fiscal income and general wealth playing a crucially important role in the empire at large is expressed in the particular organizational structure that the papyrus expressions belie. To understand the relationship between the judiciary office in Fustat and the caliph and his court, as well as with the other provincial high officials, especially the governor, and the judge's representatives throughout the province, a short overview of the developments that underpin the changed situation in the $9^{\text {th }}$ century will be given first.

\footnotetext{
${ }^{8}$ Mathieu Tillier, Histoire des Cadis Égyptiens Ahbār quḍāt Miṣr (Cairo: IFAO, 2012), 204-215.
} 
This is the authors version of "Delegation of Judicial Power in Abbasid Egypt", in Berkel M.L.M. van, Buskens L.P.H.M., Sijpesteijn P.M. (eds.), Legal Documents as Sources for the History of Muslim Societies: Studies in Honour of Rudolph Peters, Leiden: Brill, 2017.

Please cite from the published version only, DOI: 10.1163/9789004343733_005

After the Arab conquest of Egypt in 642, governors were appointed over the province by the caliphs in Medina (632-661), then in Damascus (661-750) and after that in Baghdad (from 750). Governors were typically outsiders whose offices never lasted long enough to build up a local constituency. The wujūh, members of the Arab élite in Egypt who had settled there after the conquest, however, had their own agenda and lobbied to be ruled by a representative from their own ranks or at least someone sympathetic to their concerns. ${ }^{9}$ The negotiation, sometimes expanding into outright clashes, between the interests of the caliphal center and that of the local élite members would be a continuum in the years to come. ${ }^{10}$

The governors in their turn appointed members of the local Arab élite at the next level of offices: the head of police, șăhib al-shurța, the financial officer, șăhib al-kharāj and the chief judge, $q \bar{a} d \underline{l}$, sometimes with the caliph getting involved as well. Especially the șăhib alshurța held a crucial position and belonged always to the wujūh, the local Arab notables. The governors were heavily dependent on, if not captives of these local Arab officers. Described as an oligarchy, their local knowledge and support amongst the jund, as well as their wealth and property made them indispensable for the governor's effectiveness in ruling the province. ${ }^{11}$ Each of these positions relied of course on an extensive body of lower administrative officials, clerks, scribes, guards and other personnel, most of whom originated with the native Egyptian population.

A change in the power relations within the province occurred at the end of the seventh century. At 'Abd Allāh b. al-Zubayr's (d. 72/692) proclamation of caliph at the death of caliph Yazīd I in 64/683, Arab-Egyptian kharijite supporters took control of the Egyptian capital and appointed a Zubayrid governor. Egypt's wujūh, however, overall continued in their support for the caliph in Damascus and cooperated with the reconquest of the province for the Umayyads by the caliph Marwān b. al-Ḥakam (d. 65/685) and his son 'Abd al- 'Azīz (d. 86/705) in 64-65/684. While executing any élite members who did not retract their support of Ibn al-Zubayr, Marwān instructed his son whom he appointed as governor in Egypt after

\footnotetext{
${ }^{9}$ Even in the early ninth century the notables, when consulted concerning a suitable candidate to fill the post of chief judge requested that he not be a "stranger" (gharīb). See al-Kindī (d. 350/961), Kitāb al-wulāt wa-kitāb alquḍāt (The Governors and Judges of Egypt), in E.J.W. Gibb Memorial Series 19, ed. R. Guest, The Governors and Judges of Egypt (Leiden: Brill, 1912), 433.

${ }^{10}$ Hugh Kennedy, "Egypt as a Province in the Islamic Caliphate, 641-868," in The Cambridge History of Egypt. Volume 1: Islamic Egypt, 640-1517, edited by Carl F. Petry (Cambridge: Cambridge University Press, 2008 ), 70.

${ }^{11}$ Kennedy, "Egypt as a Province in the Islamic Caliphate,” 66.
} 
This is the authors version of "Delegation of Judicial Power in Abbasid Egypt", in Berkel M.L.M. van, Buskens L.P.H.M., Sijpesteijn P.M. (eds.), Legal Documents as Sources for the History of Muslim Societies: Studies in Honour of Rudolph Peters, Leiden: Brill, 2017.

Please cite from the published version only, DOI: 10.1163/9789004343733_005

recovering its control, to rule in full cooperation with the local Arab leaders. ${ }^{12}$ From then on strong ties existed between the governor and the local élite, whose interdependency was from now on the basis of cooperation rather than competition, a policy continued under the Abbasids who maintained the locals' role in the administration.

Another phase in the relation between the capital of the caliphate and the province of Egypt began after the death of al-Hārūn in 193/809. The war between his sons and brothers alAmīn and al-Ma'mūn (between 195/811 and 198/813) brought great disturbances to Egypt. Different Arab groups introduced in Egypt as soldiers, administrators or other kinds of settlers in attempts by the caliph to increase his control over the province, had begun to challenge the position of Egypt's earlier established Arab élite. With central control diminished, and new power constellations being formed, these groups openly started to fight for influence in the province. ${ }^{13}$ Revolts, partially to protest fiscal burdens under the Arabs, partially in reaction to shifting alliances between Arab Egyptians, Christian Egyptians and incoming Arabs, which had been plaguing Egypt since the end of the $7^{\text {th }}$ and early $8^{\text {th }}$ century, added to the unrest and insecurity. From the last decade of the second century control of the province was effectively in the hands of 'Abd al- 'Azīz al-Jarawī (d. 205/820) the appointed governor who controlled the Delta with the support of the Yamani tribes, and al-Sarī b. al-Hakam (d. 205/820) who was in control of Fustat and the area to the south with the aid of the $a b n \bar{a}$, the Khurasani troops which he had led to Egypt from Baghdad. ${ }^{14}$ Andalusian refugees who arrived in 199/815 added to the disturbances, attacking and killing a number of wujüh in Alexandria in the following year. ${ }^{15}$

A return to safety in the province as well as the establishment of solid caliphal control, essential to secure the highly demanded fiscal revenues, clearly required a strong interference. This was realized in the person of 'Abd Allāh b. Țāhir, son of al-Ma'mūn's famous general whose taking control of Egypt resulted in increased centralization and influence from the East. Appointed in 206/821 as governor of the area between al-Raqqa on the Euphrates in the north and Egypt in the south and commander of the caliph's troops, 'Abd Allāh b. Ṭāhir first

\footnotetext{
12 Ibid., 71.

13 Ibid., 70-80.

${ }^{14}$ Severus of El Ashmunein, History of the Patriarchs of the Coptic Church of Alexandria. Volume 4: Menas I to Joseph (849), Arabic text edited, translated, and annotated by B. Evetts, Patrologia Orientalis 10 (1910): 428; al-Kindī, Kitāb al-wulāt, 148, 151, 161-162.

${ }^{15}$ Kennedy, "Egypt as a Province in the Islamic Caliphate,” 81.
} 
This is the authors version of "Delegation of Judicial Power in Abbasid Egypt", in Berkel M.L.M. van, Buskens L.P.H.M., Sijpesteijn P.M. (eds.), Legal Documents as Sources for the History of Muslim Societies: Studies in Honour of Rudolph Peters, Leiden: Brill, 2017.

Please cite from the published version only, DOI: 10.1163/9789004343733_005

established control in Syria and Palestine, moving his army into Egypt in 210 or 211/825826. ${ }^{16}$ With his large army, reinforced with naval ships from Syria, 'Abd Allāh was able to wrest the province from the hands of Ibn al-Sarī (in office until 211/826) and Ibn al-Jarawī (d. 251/865) who had inherited their fathers' positions after 205/820 and defeat the Andalusians in Alexandria. ${ }^{17}$ After more than 20 years, caliphal control was once again restored over the whole province.

'Abd Allāh b. Tāhir remained in Egypt until 212/827, but he ruled a very different province. The Egyptian wujūh's power had been steadily declining at the expense of representatives of the ruling military élite from the caliphal capital in Iraq who had been settling in Egypt since the late eighth century. In the struggle between al-Jarawī and al-Sarī and their sons, the old Arab élite of Egypt no longer played a decisive role. 'Abd Allāh b. Țāhir's take-over and the measures he took decisively decimated the power of the old Arab leaders at the expense of new Arab and non-Arab population groups who obtained influential positions in the administration and army, and thereby access to Egypt's resources.

'Abd Allāh's army which was now in control of the province consisted of outsiders from the East, as did the army's commanders, mostly Persian speaking Turks. ${ }^{18}$ The $10^{\text {th }}$ century chronicler of Egypt's political and judicial structure, al-Kindī, writes how the governor 'Abd Allāh b. Țāhir made use of eastern personnel. He replaced his earlier appointed head of police with a member of the $a b n \bar{a} \cdot{ }^{19}$ Caliphal control over Egypt was put in effect by the governors appointed over the province. Representing the sovereigns who were assigned the western provinces by the caliph from 213/829 onwards, the governors belonged, like their masters to the same class of eastern military commanders. Appointed for longer periods (3-4 years), the governors no longer relied on locals to fill the crucial positions of $s ̧ \bar{a} h i b$ al-shurța, șăhib al-kharāj and $q \bar{a} d \bar{l}_{.}{ }^{20}$ Instead they appointed members from their own constituency, outsiders from the East like the governors. In other words, support and cooperation from the local wujüh was no longer essential to maintain control of the province,

\footnotetext{
${ }^{16}$ al-Ṭabarī (d. 310/923), Muḥammad ibn Jarīr. Tārīkh al-rusul wa-l-mulūk, ed. Michael J. de Goeje (Leiden: Brill, 1879-1901), 3: 1087-92.

17 al-Kindī, Kitāb al-wulāt, 180.

${ }^{18}$ See also the two "Persian" army generals from Khurasān whom 'Abd Allāh b. Țāhir appointed at the head of the army he sent to Alexandria (al-Kindī, Kitāb al-wulāt, 183-184).

${ }^{19}$ Ibid., 183.

${ }^{20}$ Occasionally outsider $q \bar{a} d \grave{l} \bar{s}$ had been appointed before, see Tillier, Histoire des Cadis Égyptiens, 36.
} 
This is the authors version of "Delegation of Judicial Power in Abbasid Egypt", in Berkel M.L.M. van, Buskens L.P.H.M., Sijpesteijn P.M. (eds.), Legal Documents as Sources for the History of Muslim Societies: Studies in Honour of Rudolph Peters, Leiden: Brill, 2017.

Please cite from the published version only, DOI: 10.1163/9789004343733_005

while a new class of administrators and bureaucrats working in a new system and with new practices was put in place.

The degree to which the caliph was involved in the affairs of the province beyond the organization of local administrative structures is exemplified by the caliph appointing his brother and future caliph al-Mu' tașim as sovereign in charge of the western provinces including Egypt in 213/829. Unlike most of the other sovereigns appointed over the western provinces who mainly stayed put at the caliphal court, al-Mu tașim was in fact forced to come down in person to Egypt in 214/830 to put down a rebellion of Arabs in al-Hawf, the eastern part of the Delta. Soon, however, he left again, leaving his governor in place to rule for him. In 217/832 the caliph al-Ma'mūn in his turn came to the province, in response to yet another uprising of Arab and Christian Egyptians. Significantly, the local rulers and their military forces were unable to deal with these uprisings, while each visit by an eastern army resulted in more newcomers staying on in the province. The final turn in the relation between Egypt's Arab population and the political center was reached in 218/833 when the newly appointed caliph al-Mu 'tașim ordered his governor to abolish the dīwān, discontinuing the stipends (' $a t \bar{a}^{\prime}$ ) for the Arabs in Egypt. ${ }^{21}$ Relying on his own well-trained army of 'slave' soldiers, alMu 'tașim's abolishment of the dīwān was one of his empire-wide measures to build a new constituency while breaking the influence of traditional power blocks. The virtual lack of protest against this measure indicates the changed power relations in the province where the loss of their privileged financial position was only the last formal stage witnessing the $w u j \bar{u} h$ 's gradually diminishing place in the provincial hierarchy.

Also within the province itself the presence of Abbasid forces and administrators had resulted in centralizing measures, with stronger control being imposed from the capital Fustat in a new style and language showing eastern influences. Procedures were imposed to increase the taxes raised in the country, tightening the registration of property and with closer supervision of assessments, impositions and collections of taxes. ${ }^{22}$ The documents reflect these changes in the administration where a new terminology and novel expressions are introduced representing new - 'Persian' - chancery traditions, while at the same time

\footnotetext{
${ }^{21}$ al-Kindī, Kitāb al-wulāt, 193.

${ }^{22}$ Resulting in new tax revolts in 212/828 (al-Kindī, Kitāb al-wulāt, 185); Kosei Morimoto, The Fiscal Administration of Egypt in the Early Islamic Period (Kyoto: Dohosha, 1981), 228.
} 
This is the authors version of "Delegation of Judicial Power in Abbasid Egypt", in Berkel M.L.M. van, Buskens L.P.H.M., Sijpesteijn P.M. (eds.), Legal Documents as Sources for the History of Muslim Societies: Studies in Honour of Rudolph Peters, Leiden: Brill, 2017.

Please cite from the published version only, DOI: 10.1163/9789004343733_005

referring to the new organization based on a new hierarchical configuration put in place. ${ }^{23}$ Especially well researched by Gladys Frantz-Murphy in the case of agricultural leases and receipts, the formulaic and semantic changes introduced in the documents suggest a professionalized bureaucracy relying on officials and subjects beholden to the state. ${ }^{24}$ See for example the introduction of sultān, replacing "the Muslims" as a reference to the public authority of the province. ${ }^{25}$ Those responsible for the tax-collection are referred to no longer in terms of personal relations between them and the governor, but as representatives of the authorities in general. ${ }^{26}$ While these changes reflect the new administrative structure in place as part of the centralizing measures after the civil war, other evidence points to direct influence of eastern administrative traditions. The Persian jahbadh replaces qustāal for paymaster, while authenticating practices such as the use of seals and signatures also shows an influence from the eastern Islamic Empire. ${ }^{27}$

This then is the background against which our papyrus was written. Fundamental changes in the financial and administrative organization of the province and the empire at large had impacted the way the province of Egypt was run. Simultaneously, the penetrating presence of the Abbasid caliphate resulted in the more frequent attestation of members of the ruling family and their representatives in the form of eastern military élite members. Let us now turn to the effects of these changes on the organization of the judiciary connecting them to the situation represented in the papyrus.

\footnotetext{
${ }^{23}$ For the introduction of "Persian” administrative practices, see Gladys Frantz-Murphy, Corpus Papyrorum Raineri XXI. Arabic Agricultural Leases and Tax Receipts from Egypt 148-427 AH/765-1035 AD (Vienna: Brüder Hollinek, 2001); and Gladys Frantz-Murphy, "The Economics of State Formation in Early Islamic Egypt,” in From al-Andalus to Khurasan. Documents from the Medieval Muslim World, ed. Petra M. Sijpesteijn et al. (Leiden: Brill, 2006), 101-114.

${ }^{24}$ Frantz-Murphy, Corpus Papyrorum Raineri XXI, 40-44.

25 The first attestation of this term in an agricultural lease is dated 217/832, see Frantz-Murphy, Corpus Papyrorum Raineri XXI, 36-39.

${ }^{26}$ Frantz-Murphy, Corpus Papyrorum Raineri XXI, 122.

${ }^{27}$ For the introduction of jahbadh, see Frantz-Murphy, Corpus Papyrorum Raineri XXI, 122. For the authentication of documents, see Geoffrey Khan, “The Pre-Islamic Background of Muslim Legal Formularies,” ARAM 6 (1994): 193-224; Geoffrey Khan, “Newly Discovered Arabic Documents from Early Abbasid Khurasan,” in From al-Andalus to Khurasan. Documents from the Medieval Muslim World, ed. Petra M. Sijpesteijn et al. (Leiden: Brill, 2006), 199-216; Petra M. Sijpesteijn, "Seals and Papyri from Early Islamic Egypt,” in Seals and Sealing Practices in the Near East. Developments in Administration and Magic from Prehistory to the Islamic Period. Proceedings of an International Workshop at the Netherlands-Flemish Institute in Cairo on December 2-3, 2009,” ed. I. Regulski et al. (Leuven, Peeters: 2012).
} 
This is the authors version of "Delegation of Judicial Power in Abbasid Egypt", in Berkel M.L.M. van, Buskens L.P.H.M., Sijpesteijn P.M. (eds.), Legal Documents as Sources for the History of Muslim Societies: Studies in Honour of Rudolph Peters, Leiden: Brill, 2017.

Please cite from the published version only, DOI: 10.1163/9789004343733_005

\section{Expanding qāọ̄i justice ${ }^{28}$}

The $q \bar{a} d \bar{l}$ in the Abbasid period held indeed a very powerful position which only increased in importance with the rise of the prominence of religion-based law and its representatives or interpreters, the fuqaha '. In Egypt demographic changes added to the momentum of change. Through immigration and, to a lesser extent, through conversion of the local population, the Arab-Muslim population was growing significantly. From the eighth century onwards, migration outside the garrison cities added to the processes of conversion and acculturalisation of the Egyptian population. Developments internal to the Islamic judiciary coincided with these changes. As a consequence significant modifications can be observed in the judicial organization in Egypt from the first half of the $2^{\text {nd }} / 8^{\text {th }}$ century, characterized by an increased professionalization on the one hand and an extended presence of the court on the other. A growing Arab-Muslim population in- and outside the garrison cities increasingly looked towards Arab-Islamic institutions to record their legal transactions and deal with their disputes. While Christian and Jewish authorities continued to play a role in legal matters, Muslim courts with their greater means of enforcement became an attractive alternative for Egypt's non-Muslim communities. ${ }^{29}$ A developing Islamic judicial system on the other hand pushed for greater involvement, ${ }^{30}$ while the long administrative and managerial arm from the capital Fustat became also more pronounced. ${ }^{31}$ In short, the need for representatives of the $q \bar{a} \underline{d} \vec{\imath}$ 's court to operate outside Fustat increased and these representatives functioned in a more expert and disciplined fashion. ${ }^{32}$

These developments are exemplified by the emancipation of the $q \bar{a} d \bar{l}$ from other offices in the province. While early qā șăhib al-shurța, the office of the judge was definitely separated from that of the head of police

\footnotetext{
${ }^{28}$ The politics of the $q \bar{a} \hat{d} \vec{\imath}$ 's position in Egypt in this period is extensively described by Mathieu Tillier in his Histoire des Cadis Égyptiens Ahbār quḍāt Miṣr (33), and in his "The Qāọ̄is of Fustat-Miṣr under the Ṭūlūnids and the Ikhshīdids: The Judiciary and the Egyptian Autonomy," Journal of the American Oriental Society 131, no. 2 (2011): 207-222. I have relied heavily on his discussion for this overview.

${ }^{29}$ Maged S.A. Mikhail, From Byzantine to Islamic Egypt: Religion, Identity and Politics after the Arab Conquest (London/New York: I.B. Tauris, 2014), chapter 6; Petra M. Sijpesteijn, Shaping a Muslim State: The World of a Mid-Eighth-Century Egyptian Official (Oxford: Oxford University Press, 2013), 107-111.

${ }^{30}$ Jelle Bruning, The Rise of a Capital. On the Develoment of al-Fustât's Relationship with its Hinterland, 18/639-132/750. PhD dissertation (Leiden University, 2014), 151; Tillier, "The Qāḍ̂̄s of Fustat-Mișr under the Ṭūlūnids and the Ikhshīdids."

${ }^{31}$ Bruning, The Rise of a Capital, 148.

32 See also Mathieu Tillier's contribution to this volume.
} 
This is the authors version of "Delegation of Judicial Power in Abbasid Egypt", in Berkel M.L.M. van, Buskens L.P.H.M., Sijpesteijn P.M. (eds.), Legal Documents as Sources for the History of Muslim Societies: Studies in Honour of Rudolph Peters, Leiden: Brill, 2017.

Please cite from the published version only, DOI: 10.1163/9789004343733_005

in the early $8^{\text {th }}$ century acknowledging the importance and volume of the law-giving and executive power. ${ }^{33}$ At the same time, however, legal and administrative functions continued to be intertwined and exchangeable into the Abbasid period. ${ }^{34}$ Similarly, while there are some attestations of $q \bar{a} d \bar{l} \mathrm{~s}$ in the documentary record dating to this period, the documents offer no clear indication of the extent and character of their function especially compared to other administrative offices. $^{35}$

The $9^{\text {th }}$ century saw the accumulative effects of these developments impacted by specific historical circumstances as reflected in the documentary sources. A pronounced rise in the number of Arabic documents, including legal documents, shows that Egypt's population increasingly functioned in Arabic and did so also in Arabic-Muslim institutions. ${ }^{36}$ Mathieu Tillier, in this volume, interprets this rise in extant legal documents as a sign of an increased professionalization of the judiciary relying on documentation and archival practices, and as a witness to a more active and involved court in Egypt's countryside.

A further development was the expansion of Egyptian legal practice to form part of an extensive legal system lead by legal scholars $\left(f u q a h \bar{a}^{\prime}\right) .{ }^{37}$ The limited degree to which Egyptian scholars participated in empire-wide legal debates shows that this legal system was mostly locally defined, but there were some connections extending beyond the province. ${ }^{38}$ Maturity of the Islamic legal system coincided with the new political and religious order with an the increased role for religious scholars ( 'ulama ') as an independent voice of religious authority following the period of the mihnna introduced by caliph al-Ma'mūn in 218/833 and continuing until $234 / 848$ or $237 / 852 .{ }^{39}$ While the document that is the subject of this article

\footnotetext{
${ }^{33}$ Until 89/708 several $q \bar{a} \underline{d} \bar{\imath} \mathrm{s}$ had also held the function of șăhib al-shurța, see Tillier, Histoire des Cadis Égyptiens Ahbār quḍāt Miṣr, 20.

${ }^{34}$ See Tillier's discussion in this volume, extending Joseph Schacht’s description of the Umayyad $q \bar{a} d \bar{\imath}$ as a legal secretary to the governor to the chief judge in early Abbasid Egypt.

${ }^{35}$ See the commentary to Sijpesteijn 2013, no. 26. See also the contribution of Tillier in this volume.

${ }^{36}$ Sijpesteijn, Shaping a Muslim State, 111. See the Christians appearing in Arabic-Islamic contracts (CPR XXVI). See also the two tenth-century contracts written up in Arabic according to Islamic legal rules which had to be translated orally for the parties into Coptic (Frantz-Murphy 1981, nos. 1 and 2) and the Arabic marriage contracts drawn up for two Christian parties according to Islamic legal principles (Abbott 1941, nos. 1 and 2). All these documents originate in the Fayyūm.

${ }^{37}$ Discussed in this volume by Mathieu Tillier.

${ }^{38}$ As discussed by Mathieu Tillier in his lecture "Local Tradition and Imperial Law in Umayyad Egypt," at the conference "Egypt Connected: Cultural, Economic, Political and Military Interactions (500-1000 CE)” which took place on June 18-20, 2015 at Leiden University.

${ }^{39} Q \bar{a} d \bar{l} \bar{s}$ cannot of course be equaled to fuqahā'. The $q \bar{a} d \bar{l} \bar{s}$ of Umayyad Egypt do not seem to have played an especially important role in religious scholarship of the time (G.H.A. Juynboll, Muslim Tradition Studies in Chronology, Provenance and Authorship of Early Hadith (Cambridge: Cambridge University Press,
} 
This is the authors version of "Delegation of Judicial Power in Abbasid Egypt", in Berkel M.L.M. van, Buskens L.P.H.M., Sijpesteijn P.M. (eds.), Legal Documents as Sources for the History of Muslim Societies: Studies in Honour of Rudolph Peters, Leiden: Brill, 2017.

Please cite from the published version only, DOI: 10.1163/9789004343733_005

predates the mihna, the development of religious scholarship leading to a discussion about who held the ultimate religious authority in the Muslim community was already a significant factor.

While Arabicisation and acculturalization as well as the growth of the Law definitely played a role in the increased presence of a professionalized Muslim court in Egypt's countryside, political-administrative measures were important too. The centralizing procedures undertaken by al-Ma'mūn's regime after his victory in the civil war in the person of 'Abd Allāh b. Țāhir after his take-over of the province in 833 have already been described. Similarly, the impact of the arrival of Persian-Turkish administrators and militaries on the administrative infrastructure of the province have been discussed above. Both these developments greatly impacted the relation between the caliph and the $q \bar{a} d \bar{\imath}$ of Egypt as well as the position of the chief judge and his representatives in the province.

Contrary to governors who were always appointed directly by the caliph to the provinces, the $q \bar{a} d \bar{l}$ was a local appointee who was regularly installed by the governor, but was also often (re)confirmed by the caliph. ${ }^{40}$ A clear pattern exists between centralizing efforts of the caliphal court and its involvement in the appointment of judges in Egypt, and the caliphs were always involved from al-Ma'mūn's rule onwards. ${ }^{41}$ Accountable to the official (governor or caliph) who invested him with his title and position, the $q \bar{a} \underline{d} \bar{l}$ maintained direct contact with the ruler. This could restrict the judge's independence, but also transferred status onto him. ${ }^{42}$ The caliph’s ambitions of control of the provinces through the office of the $q \bar{a} d \underline{\imath}$

1983), 80; but see Mathieu Tillier, "Scribes et enqueteurs: note sur le personnel judiciaire en Egypte aux quatre premiers siecles de l'hégire,” Journal of the Social and Economic History of the Orient 54 (2011): 370-404, n. 94.

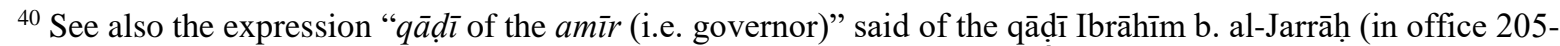
211/820-826) (al-Kindī, Quḍāt, 431-432). Cf. Tillier, Histoire des Cadis Égyptiens Ahbāar quḍāt Miṣr, 31.

${ }^{41}$ For an overview of who appointed the $q \bar{a} \hat{d} \bar{\imath}$ in Fustat from the conquest until the Tiūlunid period, see the table in Tillier, Histoire des Cadis Égyptiens Ahbār qud̄āt Mișr, 24-30; for the period 237-366/851-976, see Tillier, Vies des cadis de Miṣr 237/851-366/976 (Cairo: Institut français d'archéologie orientale, 2002), 20-25. Even Ahmmad b. Țūlūn (d. 270/884) as semi-independent viceroy of Egypt accepted the qā (Tillier, Vies des cadis de Miṣr 237/851-366/976, 21-22). The governor 'Abd Allāh b. Ṭāhir appointed the qā $\bar{d} \bar{\imath}$ 'Īsā b. al-Munkadir, the same of our papyrus, but he did so after long deliberation, and leaving the judgeship vacant for more than a year while legal cases were being dealt with in the mazālim court whose heads were appointed by the governor too. Subsequent governors also sometimes appointed someone over the mazālim court while the $q \bar{a} d \bar{l}$ was only appointed several years later by the caliph. See for example the appointment of Ishāq $b$. Ismā '̄il (in office 215/830) by the governor 'Abdawayh b. Jabala (in office 215-216/830-831), Muhammad b. 'Abbād (in office 215-217/830-832) by the governor Kaydar Nașr b. 'Abd Allāh (in office 217-219/832-834) and 'Īsā b. Lahī' a (in office 235-237/850-851) by the governor Isḥāq b. Yahyā (in office 235-236/849-850).

${ }^{42}$ For examples of direct involvement by the caliph al-Walīd (r. 86-96/705-715) in Damascus in cases dealt with by the Egyptian $q \bar{a} d \bar{l}$, see Yaacov Lev, “Coptic Rebellions and the Islamization of Medieval Egypt (8th-10th 
This is the authors version of "Delegation of Judicial Power in Abbasid Egypt", in Berkel M.L.M. van, Buskens L.P.H.M., Sijpesteijn P.M. (eds.), Legal Documents as Sources for the History of Muslim Societies: Studies in Honour of Rudolph Peters, Leiden: Brill, 2017.

Please cite from the published version only, DOI: 10.1163/9789004343733_005

were, however, sometimes thwarted by weakness at the centre, for example at times of civil war, or by governors taking matters in their own hand. ${ }^{43}$ Moreover, from the Abbasids' move of the capital to Baghdad, Egypt was sufficiently remote to make effective control difficult especially when the local Arab élite or the governor opposed it. ${ }^{44}$

Even those $q \bar{a} d \bar{l} \overline{\mathrm{s}}$ who were appointed by the caliph or their governors, could form an opposing force. It is exactly when 'Abd Allāh b. Țāhir was imposing direct and firm control on Egypt that he came into conflict with two consecutive judges. Ibrāhīm b. al-Jarrāḥ (in office 206-211/821-826) was dismissed by the governor when the latter found out about Ibrāhīm's letter in support of the rebellious governor Ibn al-Sarī. The post of $q \bar{a} d \bar{l}$ remained vacant for more than a year, with cases being dealt with in the mazālim court. The mazalim court of appeals fell directly under the governor. ${ }^{45}$ It is interesting to note that in the process

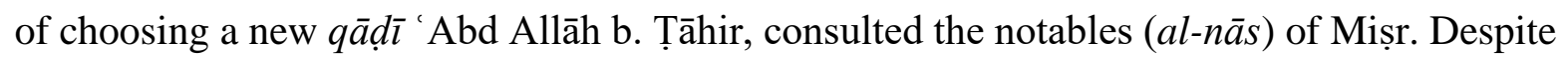
'Abd Allāh b. Țāhir's position as military conqueror and his exposing his absolute power by dismissing the $q \bar{a} \underline{̣} \bar{\imath}$ Ibrāhīm b. al-Jarrāḥ and not installing a new $q \bar{a} d \underline{\imath} \bar{l}$ immediately, he obviously felt the need to involve the local notables and give them a voice and a feeling of empowerment in the process of the appointment of local officials. Finally on 10 Rajab 212/ 5 October 827 'İsā b. al-Munkadir was appointed seemingly as a compromise figure and after different candidates were put forward. The governor, of course having the last say in the choice. ${ }^{46}$ Besides having been dependent on the governor for his appointment, 'İsā b. alMunkadir had another reason to be grateful to the governor as the latter decided to provide him with a daily salary because he was "poor,” besides a sign-up bonus of one thousand

Century): Medieval and Modern Perceptions,” Jerusalem Studies in Arabic and Islam 39 (2012): 303-344. 'Umar b. 'Abd al- 'Azīz (r. 98-101/7171-720) also communicated directly with the qā $\bar{d} \bar{l}$ of Egypt (Tillier, Histoire des Cadis Égyptiens Ahbār quạāt Miṣr, 31, n. 142).

${ }^{43}$ In his Histoire des Cadis Égyptiens Ahbār quḍāt Miṣr (32) Tillier describes several cases when Abbasid governors interfered in the appointment of the $q \bar{a} \underline{\bar{l}} \overline{\text {. }}$.

${ }^{44}$ Tillier writes that caliphal control over the office of the $q \bar{a} d \bar{l}$ seems to have been even harder to maintain in Egypt than in Iraq (Histoire des Cadis Égyptiens Ahbār quḍàt Miṣr, 32).

${ }^{45}$ Ibrāhīm b. al-Jarrāh was removed from office in Rabī' I 211/June-July 826 (Ibn Hajar gives the alternative date Jumādā I 211/Augus 826. See Tillier, Histoire des Cadis Égyptiens Ahbār quḍāt Miṣr, 204. n. 862), while 'Īsā b. al-Munkadir was not appointed until 10 Rajab 212/5 October 827. During this period the mazālim court was headed by 'Aț̣āaf b. Ghazwān (in office 211-212/826-827) (al-Kind̄̄, Kitāb al-wulāt, 432-433). Tillier showed how rulers resorted to installing (only) a maz̄a lim courts while dismissing a troublesome $q \bar{a} d \underline{\bar{l}}$, see his "Qāḍ̂̄-s and the Political Use of the Maẓālim Jurisidiction under the 'Abbāsids," in Public Violence in Islamic Societies: Power, Discipline and the Construction of the Public Sphere, 7th-18th Centuries CE, ed. C. Lange and M. Fierro (Edinburgh: Edinburgh University Press, 2009), 42-66.

${ }^{46}$ al-Kindī, Kitāb al-wulāt, 433-435 (tr. Tillier, Histoire des Cadis Égyptiens Ahbāar quḍāt Miṣr, 204-207). 
This is the authors version of "Delegation of Judicial Power in Abbasid Egypt", in Berkel M.L.M. van, Buskens L.P.H.M., Sijpesteijn P.M. (eds.), Legal Documents as Sources for the History of Muslim Societies: Studies in Honour of Rudolph Peters, Leiden: Brill, 2017.

Please cite from the published version only, DOI: 10.1163/9789004343733_005

dinars. ${ }^{47}$ The position of 'Īsā b. al-Munkadir, however, was compromised when he protested the appointment of the governor Abū Ishāa al-Mu tașim appointed over the western provinces in a letter to the caliph al-Ma'mūn. In 214/829 Abū Isḥāq al-Mu'taṣim dismissed and imprisoned 'Īsā b. al-Munkadir. A year later Abū Ishāạ al-Mu'tașim, who by now had left Egypt, ordered him to be exiled to Iraq where he died in prison in 220/835. ${ }^{48}$

\section{Delegation and legitimization}

Unlike other provinces, where major towns often had two qā $d \bar{\imath} \mathrm{s}$, Fustat always only knew one chief judge who, together with his office, his scribes and other aids, was responsible for the maintenance of justice in the city and its dependent countryside. ${ }^{49}$ Literary sources mention $q \bar{a} d \bar{l} \bar{l}$ in place in Alexandria from the end of the first/early eighth century, somewhat earlier than in other provinces of the Empire. The presence of $q \bar{a} d \underline{\imath} \bar{s}$ in Alexandria is presumably related to the city's dominant position in the province which remained at a par with the official capital Fustat. ${ }^{50}$ At the same time the presence of a $q \bar{a} d \underline{\imath}$ in Alexandria at this early moment, might explain why Fustat always only had one $q \bar{a} \underline{d} \bar{l}$ whose work, with a partner in place in the other major Egyptian city, remained manageable. ${ }^{51}$

$Q \bar{a} d \bar{l} \bar{s}$ operating outside the capital, albeit without an indication of the extent of their mandate, start to be attested in the papyri from the mid-second/eighth century onwards. That is when in other provinces $q \bar{a} d \underline{\imath} \bar{s}$ are said to be appointed outside provincial capitals as well. ${ }^{52}$ Besides Alexandria, the sources report that from the $3^{\text {rd }} / 9^{\text {th }}$ century other towns such as

\footnotetext{
${ }^{47}$ Of seven dinars per day or four thousand dirhams per month. Al-Kindī writes this custom was standard from that moment onwards (al-Kindī, Kitāb al-wulāt, 435). But see the receipt also recorded by al-Kindī (Kitāb alwulāt, 354) recording the payment of twenty dinars for two months of salary for the qā $\bar{d} \bar{l}$ 'Abd al-Rahmān b. Sālim (in office Muharram 128/October 745-Ramaḍān 133/751). Cf. W. al-Qāḍ̄ị, “An Umayyad Papyrus in alKindī's Kitāb al-Quḍāt?,” Der Islam 84 (2007): 200-245.

${ }^{48}$ Tillier's translation of al-Kindī's biography of 'İsā b. al-Munkadir contains exhaustive information from other Arabic sources on the judge's life. His death date is based on Ibn Yūnus (d. 347/958), see Ibn Yūnus, Ta'rīkh Ibn Yūnus al-Șadafi, ed. 'A.F. 'Abd al-Fattāḥ (Beirut: 2000), 215, n. 914.

${ }^{49}$ Tillier, Histoire des Cadis Égyptiens Ahbār quḍat Miṣr, 23, n. 116.

${ }^{50}$ Bruning, The Rise of a Capital, chapter 2. For the exceptional position of Fustat in having always only one $q \bar{a} \underline{̣} \bar{l}$ as opposed to Damascus and towns in Iraq, see Tillier, Histoire des Cadis Égyptiens Ahbār quḍāt Miṣr, 23, n. 116; Tillier, "Qāọ̄īs and the Political Use of the Maẓālim Jurisidiction under the 'Abbāsids," 281-284.

${ }^{51}$ Tillier, Histoire des Cadis Égyptiens Ahbār quḍāt Miṣr, 23.

${ }^{52}$ In his The Rise of a Capital (141-142) Bruning discusses examples from Egypt and Syria. Tillier lists examples from Iraq in his Les cadis d'Iraq et l'État abbasside (132/750-334/945) (Damascus: Presses de l'Ifpo, 2009).
} 
This is the authors version of "Delegation of Judicial Power in Abbasid Egypt", in Berkel M.L.M. van, Buskens L.P.H.M., Sijpesteijn P.M. (eds.), Legal Documents as Sources for the History of Muslim Societies: Studies in Honour of Rudolph Peters, Leiden: Brill, 2017.

Please cite from the published version only, DOI: 10.1163/9789004343733_005

Akhmim and Rashid (Rosetta) had $q \bar{a} d \bar{l} \bar{s}$ as well. ${ }^{53}$ Although these officials were all equally called $q \bar{a} d \bar{l}$, the judge in Fustat clearly topped the judicial hierarchy and important cases continued to be referred to the chief judge in the capital. ${ }^{54}$

Deputies of $q \bar{a} \underline{d} \bar{\imath}$ s are mentioned in the literary sources to have been in place from the end of the $8^{\text {th }} /$ early $9^{\text {th }}$ century onwards in the Fayyum and in Alexandria. ${ }^{55}$ These sources use the same root kh-l-f to indicate the legal deputies. ${ }^{56}$ The papyrus edited above not only mentions one representative, but a chain of representatives with the lowest office in the Fayyum oasis and another one in between that and the $q \bar{a} d \underline{\imath}$ 's office in the capital Fustat. It shows not only the degree to which the judiciary and its institutions had expanded and proliferated, with offices multiplying and dependences of the provincial court in the countryside increasing, but also the level of centralization and hierarchy extending from the province’s capital to its sub-regions. In those expanding and proliferating courts officials such as secretaries, scribes, examiners of witnesses and the like multiplied. ${ }^{57}$

'Īsā b. al-Munkadir's office, the $q \bar{a} \underline{d} \bar{\imath}$ under whose judgeship the papyrus was produced, shows these two processes in action. Appointed over the judiciary and the appeals

\footnotetext{
${ }^{53}$ For Marthad b. 'Abd Allāh al-Yazanī (d. 90/708-9) and other qāọ̄̄s in the first/seventh-second/eighth centuries, see Bruning, The Rise of a Capital, 141-148. For later examples, see Tillier, Histoire des Cadis Égyptiens Ahbār quạ̄àt Miṣr, 23-24.

${ }^{54}$ See also Bruning's reconstruction of the careers of Marthad b. 'Abd Allāh al-Yazanī and Yazīd b. 'Abd Allāh al-Hadramī whose rising in the administrative hierarchy included a move from a provincial legal office to that of $q \bar{a} \underline{d} \bar{\imath}$ in Fustat (The Rise of a Capital, 142-148). Mathieu Tillier warns against accepting the ascription of the title $q \bar{a} d \bar{l}$ by the narrative sources to judicial officials outside Fustat, suggesting that, especially for the earlier period, these should be interpreted rather as administrative officials wielding judicial power as litepart of their position (Histoire des Cadis Égyptiens Ahbār quḍāt Mișr, 24). The attestation of $q \bar{a} d \bar{l} \overline{\mathrm{s}} \mathrm{s}$ in the papyri, however, suggests that such an office did exist (at times) beyond the capital, while the chief qāọī located in Fustat might have been indicated with an adjusted title (See for example qā $\bar{d} \bar{l}$ ahl miṣr in the papyrus dating from 141/758-759 edited by Hinds and Sakkout, see Martin Hinds and Hamdi Sakkout, "A Letter from the Governor of Egypt to the King of Nubia and Muqurra Concerning Egyptian-Nubian Relations in 141/758,” in Studia Arabica et Islamica.

Festschrift for Ihsān 'Abbās on his Sixtieth Birthday, ed. Ihsan Abbas et al. (Beirut: American University of Beirut, 1981), 202-229. The expression appears in line 46 of the document). For an overview of the attestations of $q \bar{a} d \bar{l} \bar{s}$ in the papyri, see Sijpesteijn, Shaping a Muslim State, no. 26, Fayyūm, ca. 730. For cases outside Fustat being referred to the main judge in Fustat, see for example the case of the killing of an Egyptian merchant in Nubia in a papyrus dating to the governorship of governor Mūsā b. Ka 'b (in office 141/758-759), see Hinds and Sakkout, "A Letter From the Governor of Egypt."

55 Tillier, Histoire des Cadis Égyptiens Ahbār quḍāt Miṣr, 23.

${ }^{56}$ Wa-kataba ilayya an akhlafahu bi-l-fayyūm (Qāḍ̄ 'Iyād, Tart̄̄b al-Madārik, II, 463); History of the Patriarchs, vol. 4. All sources are cited in Tillier, Histoire des Cadis Égyptiens Ahbār quḍāt Miṣr, 23, n. 117. See also the discussion in Hussein F.S. Kasassbeh, The Office of Qā $\bar{l} \bar{i}$ in the Early 'Abbāsid Caliphate (132-247/750-861), PhD dissertation (London: SOAS, 1990), 289-292. I am grateful to Jelle Bruning for introducing me to this reference (see also Bruning The Rise of a Capital, 144, n. 75).

${ }^{57}$ For the expansion of the lower officials working at the courts, see Mathieu Tillier, "Scribes et enquêteurs: note sur le personnel judiciaire en Égypte aux quatre premiers siècles de l’hégire,” Journal of the Social and Economic History of the Orient 54 (2011): 370-404.
} 
This is the authors version of "Delegation of Judicial Power in Abbasid Egypt", in Berkel M.L.M. van, Buskens L.P.H.M., Sijpesteijn P.M. (eds.), Legal Documents as Sources for the History of Muslim Societies: Studies in Honour of Rudolph Peters, Leiden: Brill, 2017.

Please cite from the published version only, DOI: 10.1163/9789004343733_005

courts (maz̄ālim) together, 'İsā b. al-Munkadir was chosen to be the perfect representative of the caliph's interest after a period in which the ruler's representative in Egypt 'Abd Allāh b. Țāhir had kept direct control over the law court through the office of the mazālim. The centralizing ambitions of the regime in Egypt were expressed through the chain of representatives (khalīfa) that the sender of the papyrus, Hasan b. Ya 'qūb who was located outside the capital in the oasis Fayyum is identified with. At his appointment 'Isā b. alMunkadir, it is said, appointed a new set of officials in his office: the main scribe and secretaries, a supervisor and someone in charge of examining upright witnesses are all replaced by him. ${ }^{58}$ Not only does this action symbolize the arrival of a new powerbase put in place under the direct auspices of the caliphal court, it also refers to the bureaucracy on which the law court by now relied.

It is ironic that it is exactly 'Îsā b. al-Munkadir who defies the political hierarchy within the Empire by turning directly to the caliph al-Ma'mūn to protest the appointment of the caliph's brother and heir apparent as sovereign over Egypt and the other western provinces. As described above the letter caused the judge’s downfall and removal from office.

The new administrative and political order put in place by 'Abd Allāh b. TTāhir enabled the rise of a service élite in Egypt. The status and authority of the new administrative notables were no longer based on their belonging to the earliest settled Arab families, but rather on their function within or relation with the state structure, which appears in the documents under the abstract term sulțān. Hence, association with representatives of that administration were more important when establishing one’s position than personal relations. Social background remained of course important, with the Turkish-Persian military and bureaucratic culture now being dominant.

This emphasis on the administrative hierarchy is exemplified by the papyrus edited above. Hasan b. Ya 'qūb, the sender of the document, identifies himself not only as being part of the judiciary headed by the $q \bar{a} \underline{d} \bar{\imath}$ in Fustat in a general way, but connects himself through a chain of representatives, of whom he is the last and third one, directly with the $q \bar{a} d \bar{l}$. While representing a government office in the Fayyūm oasis, Hasan b. Ya qūb, also refers to the direct ties that link him in the countryside with the capital. It is an expression of extreme centralization when observed from the capital, with authority being referred onto the judge in

\footnotetext{
58 al-Kindī, Kitāb al-wulāt, 435.
} 
This is the authors version of "Delegation of Judicial Power in Abbasid Egypt", in Berkel M.L.M. van, Buskens L.P.H.M., Sijpesteijn P.M. (eds.), Legal Documents as Sources for the History of Muslim Societies: Studies in Honour of Rudolph Peters, Leiden: Brill, 2017.

Please cite from the published version only, DOI: 10.1163/9789004343733_005

the province through his link to the chief judge. Seen from Hasan b. Ya 'qūb's point of view, however, the same chain empowers as it disseminates the court's power to lower layers in the judiciary. As identified in this papyrus, Hasan b. Ya 'qūb is an official representative of the judiciary in the countryside and a member of Egypt's service elite. The same expression tying the official giving judgements in the Fayyum oasis to the court in Fustat, operates both ways. It is a nice example of how centralised expressions of power implicated both sides of the chain in a reciprocal system of imposition and reception.

At the same time the first point of contact in the judicial hierarchy for Hasan b. Ya 'qūb would have been Yahyā ibn Sa 'īd, the official placed between himself and the qā 'İsā b. al-Munkadir. The papyrus also shows thus the different administrative layers that connected the district of the Fayyum oasis with the capital Fustat. The literary sources do not discuss such a tier in the judiciary, but one wonders whether it can be associated to a similar division in the fiscal administration. When the Arabs arrived in Egypt in 639, they initially maintained the division in five larger districts (eparchies) for administrative and fiscal purposes. From the end of the seventh century, however, documents and narrative sources describe the existence of a partition in two main sub-provinces: the Șa 'īd (Upper Egypt) and Așfal al-Arḍ (the Delta). ${ }^{59}$ While there were offices and officials working for the two districts in the capital Fustat, officials responsible for the Upper and Lower Egyptian areas were also located or at least operated in situ. This situation continued into the Abbasid period when the references in the documents to this division and the two offices in fact increase. Was the judiciary subjected to a similar division of the province in two with Yahyā ibn Sa $\overline{1}$ d heading the Upper Egyptian one?

\section{Conclusion}

With the edition of the papyrus in this article, 'İsā b. al-Munkadir has become, with three papyrological attestations, the $q \bar{a} d \underline{\imath}$ most present in the documentary record. ${ }^{60}$ The papyrus

\footnotetext{
${ }^{59}$ Sijpesteijn, Shaping a Muslim State, 107; 119, n. 14. For the changes in the administrative division of Egypt in the $8^{\text {th }}$ century in general, see ibid., ch. 2 .

${ }^{60}$ For examples of other judges attested in the papyri, see for example: al-Mufaḍal b. Faḍāla (d. ca. 181/797). Mathieu Tillier, "Deux papyrus judiciaires de Fusțāt (IIe /VIIIe siècle)," Chronique d'Egypte 89 (2014): 412445, text 2. Ghawth b. Sulaymān (d. 168/784) appears in two papyri, see Tillier, "Deux papyrus judiciaires," text
} 
This is the authors version of "Delegation of Judicial Power in Abbasid Egypt", in Berkel M.L.M. van, Buskens L.P.H.M., Sijpesteijn P.M. (eds.), Legal Documents as Sources for the History of Muslim Societies: Studies in Honour of Rudolph Peters, Leiden: Brill, 2017.

Please cite from the published version only, DOI: 10.1163/9789004343733_005

edited in this article places him, moreover, clearly at the top of a chain of offices extending from his position as $q \bar{a} d \bar{l}$ in Fustat via a delegate in the countryside to a judicial officer responsible for the Fayyūm oasis. While delegated judicial officials operating in the Egyptian countryside occasionally occur in the papyrological record, the kind of hierarchical dependency as presented in this papyrus is not previously attested. ${ }^{61}$ The $q \bar{a} d \underline{\imath}$ 's presence in the papyri in the form in which it occurs in this text confirms the changes in the administrative and political organization of the province imposed by 'Abd Allāh b. TTāhir after his takeover of Egypt after the unrest surrounding the civil war between al-Amīn and al-Ma'mūn.

While clearly using the qāọi in Fustat as the ultimate focus, the papyrus also points to the multitude of layers in the judiciary administrative hierarchy showing a complex system of control from the center over the smaller districts like the Fayyum. Offices in between the centrally located $q \bar{a} d \underline{l}$ and his local representatives diffused central rule and discipline, but also offered a reference point for local officials where cases could be dealt with before or without passing them on to the highest authority in the capital. It shows that within the tighter organized, centrally structured administration a multiple leveled hierarchy existed.

'Abd Allāh b. Țāhir took a while to appoint a new qăḍ̄ after his arrival in Egypt, leaving the office vacant for two years, while all cases were dealt with in the mazālim court which fell directly under his governorship. When he appointed 'İsā b. al-Munkadir he did so in consultation with the local notables. ${ }^{62}$ Those notables no longer represented exclusively the interests of the first Arab settlers in Egypt, but consisted of the many new groups - Arab immigrants, Turkish-Persian administrators and militaries - that had obtained a position of power at the provincial court. While involving new groups in the administration of the province, the administration, including the judiciary were profoundly reformed to allow for stronger central control from the caliphal capital through its representatives, the governors and

1; M. Hinds and H. Sakkout, "A Letter from the Governor of Egypt to the King of Nubia and Muqurra Concerning Egyptian-Nubian Relations in 141/758,” in Studia Arabica et Islamica. Festschrift for Ihsān 'Abbās on his Sixtieth Birthday, ed. W. al-Qadi, Beirut, 1981), 209-229. See also the overview of attestations in the papyri in Mathieu Tillier's article in this volume.

${ }^{61}$ While literary sources identify Yazīd b. 'Abd Allāh al-Hadramī as representative of the qā dī Ghawth b. Sulaymān in Ikhmīm and Tahțā, in the single papyrus where he is attested he is referred to as pagarch, administrative governor of Ikhmīm (P.Cair.Arab. III 167; Bruning, The Rise of a Capital, 144-148; Mathieu Tillier, "Du pagarque au cadi: ruptures et continuités dans l’administration judiciaire de la Haute-Égypte (IerIIIe/Vie-IXe siècle),” Médiévales 64 (2013): 32.

62 al-Kindī, Kitāb al-wulāt. 
This is the authors version of "Delegation of Judicial Power in Abbasid Egypt", in Berkel M.L.M. van, Buskens L.P.H.M., Sijpesteijn P.M. (eds.), Legal Documents as Sources for the History of Muslim Societies: Studies in Honour of Rudolph Peters, Leiden: Brill, 2017.

Please cite from the published version only, DOI: 10.1163/9789004343733_005

chief judges in Egypt. Also within the province a centralization was imposed extending through the different branches of the administration.

Taking a local point of view, namely from the district of the Fayyum, our papyrus also shows the other side of this process. Namely that the ties that drew in the local legal representative, Hasan b. Ya 'qūb, into the $q \bar{a} d \vec{\imath}$ ’s court and jurisdiction, the association with the chief judge also empowered this local official and legitimized his authority vis-à-vis his constituency. The emphasis on the judicial administrative pyramid with its different layers, kept Ḥasan b. Ya'qūb attentative to his place in the pecking order, but also made him part of the larger structure, offering him a place in the judicial configuration with responsibilities, but also rights and entitlements.

By the mid-ninth century, Egyptians operated for a large part in Arabic in the written domain as the increase in public and private Arabic documents exchanged between Muslim and non-Muslim Egyptians shows. Many of these documents concern the legal domain, from administrative exchanges related to tax payments, to debt acknowledgements and property sales and even extending to marriage contracts. Non-Muslims, moreover, regularly sought recourse in Muslim law courts. ${ }^{63}$ This development was as much a result of the Arabicisation and Islamicisation of the Egyptian population as of the expansion and professionalisation of the Muslim judiciary which replaced other forms of administrative legal practice and Christian and Jewish religious legal institutions. ${ }^{64}$

The papyrus edited in this paper, shows how these two developments coincided - the advanced application and use by the population of the Muslim legal institutions and the imposition of more centralized administrative and judicial apparatus in the province presenting a new phase in Egypt's political structure. Presenting himself through a chain of representatives as the delegate in the Fayyūm oasis of the chief $q \bar{a} d \bar{l} \bar{i}$ in Fustat, the individual legal official who produced our papyrus reflects this new configuration. On the one hand his presence in the Fayyūm oasis indicates to what extent the judiciary had expanded, while his association with the $q \bar{a} d \underline{\imath}$ in the provincial capital explicitly shows his ties with the central judiciary office.

\footnotetext{
${ }^{63}$ Uriel Simonsohn, A Common Justice: The Legal Allegiances of Christians and Jews under Early Islam (Philadelphia: University of Pennsylvania Press, 2011).

${ }^{64}$ For such non-Islamic legal institutions, see Simonsohn, A Common Justice.
} 
This is the authors version of "Delegation of Judicial Power in Abbasid Egypt", in Berkel M.L.M. van, Buskens L.P.H.M., Sijpesteijn P.M. (eds.), Legal Documents as Sources for the History of Muslim Societies: Studies in Honour of Rudolph Peters, Leiden: Brill, 2017.

Please cite from the published version only, DOI: 10.1163/9789004343733_005

The document thus offers in its minimalist and damaged form very important evidence of how these historical processes were expressed in practice. Or as this volume intends to show: how documents form important historical sources, correcting and adding to the information available from the literary texts. 
This is the authors version of "Delegation of Judicial Power in Abbasid Egypt", in Berkel M.L.M. van, Buskens L.P.H.M., Sijpesteijn P.M. (eds.), Legal Documents as Sources for the History of Muslim Societies: Studies in Honour of Rudolph Peters, Leiden: Brill, 2017.

Please cite from the published version only, DOI: 10.1163/9789004343733_005

\section{Bibliography}

Abbott, Nabia. “Arabic Marriage Contracts among the Copts.” Zeitschrift der Deutschen morgenländischen Gesellschaft 95 (1941): 59-81.

Bligh-Abramski, Irit. “The Judiciary ( $q \bar{a} d \bar{l} \bar{s})$ as a Governmental-Administrative Tool in Early Islam.” Journal of the Economic and Social History of the Orient 35 (1992): 40-71.

Bruning, Jelle. The Rise of a Capital. On the Develoment of al-Fustāț’s Relationship with its Hinterland, 18/639-132/750. PhD dissertation. Leiden University, 2014.

CPR XXVI = ed. M.H. Thung, Arabische juristische Urkunden aus der Papyrussammlung der Österreichischen Nationalbibliothek. Leipzig: De Gruyter, 2006.

Frantz-Murphy, Gladys. Corpus Papyrorum Raineri XXI. Arabic Agricultural Leases and Tax Receipts from Egypt 148-427 AH/765-1035 AD. Vienna: Brüder Hollinek, 2001.

Frantz-Murphy, Gladys. “A Comparison of the Arabic and Earlier Egyptian Contract Formularies. Part I: the Arab Contracts from Egypt (3rd/9th-5th/11th Centuries).” Journal of Near Eastern Studies 40, no. 1-2 (1981): 203-225, 355-356.

Frantz-Murphy, Gladys. “The Economics of State Formation in Early Islamic Egypt.” In From al-Andalus to Khurasan. Documents from the Medieval Muslim World, edited by Petra M. Sijpesteijn, Lennart Sundelin, Sofia T. Tovar and Amalia Zomeño, 101-114. Leiden: Brill, 2006.

Hinds, Martin, and Hamdi Sakkout. "A Letter from the Governor of Egypt to the King of Nubia and Muqurra Concerning Egyptian-Nubian Relations in 141/758.” In Studia Arabica et Islamica. Festschrift for Iḥsān 'Abbās on his Sixtieth Birthday, edited by Ihsan Abbas, Wadad al-Qadi, Ramzi Baalbaki and Peter Bachmann, 202-229. Beirut: American University of Beirut, 1981. 
This is the authors version of "Delegation of Judicial Power in Abbasid Egypt", in Berkel M.L.M. van, Buskens L.P.H.M., Sijpesteijn P.M. (eds.), Legal Documents as Sources for the History of Muslim Societies: Studies in Honour of Rudolph Peters, Leiden: Brill, 2017.

Please cite from the published version only, DOI: 10.1163/9789004343733_005

Ibn Yūnus (d. 347/958). Ta'rīkh Ibn Yūnus al-Ṣadafí. Edited by 'A.F. 'Abd al-Fattāh. Beirut: 2000.

Juynboll, Gautier H. A. Muslim Tradition. Studies in Chronology, Provenance and Authorship of Early Hadith. Cambridge: Cambridge University Press, 1983.

Kasassbeh, Hussein F.S. The Office of Qāḍ̄ in the Early 'Abbāsid Caliphate (132-247/750861). PhD dissertation. London: School of Oriental and African Studies, 1990.

Kennedy, Hugh. "Central Government and Provincial Élites in the Early 'Abbāsid Caliphate." Bulletin of the School of Oriental and African Studies 44 (1981), 26-38.

Kennedy, Hugh. “Egypt as a Province in the Islamic Caliphate, 641-868.” In The Cambridge History of Egypt. Volume 1: Islamic Egypt, 640-1517, edited by Carl F. Petry, 62-85.

Cambridge: Cambridge University Press, 2008.

Khan, Geoffrey. “The Pre-Islamic Background of Muslim Legal Formularies.” ARAM 6 (1994): 193-224.

Khan, Geoffrey. “Newly Discovered Arabic Documents from Early Abbasid Khurasan.” In From al-Andalus to Khurasan. Documents from the Medieval Muslim World, edited by Petra M. Sijpesteijn, Lennart Sundelin, Sofia T. Tovar, and Amalia Zomeño, 199-216. Leiden: Brill, 2006.

al-Kindī (d. 350/961). Kitāb al-wulāt wa-kitāb al-quḍāt. E.J.W. Gibb Memorial Series 19, edited by R. Guest, The Governors and Judges of Egypt. Leiden: Brill, 1912.

Lev, Yaacov. "Coptic Rebellions and the Islamization of Medieval Egypt (8 $8^{\text {th }}$-10th Century): Medieval and Modern Perceptions.” Jerusalem Studies in Arabic and Islam 39 (2012): 303344. 
This is the authors version of "Delegation of Judicial Power in Abbasid Egypt", in Berkel M.L.M. van, Buskens L.P.H.M., Sijpesteijn P.M. (eds.), Legal Documents as Sources for the History of Muslim Societies: Studies in Honour of Rudolph Peters, Leiden: Brill, 2017.

Please cite from the published version only, DOI: 10.1163/9789004343733_005

Mikhail, Maged S.A. From Byzantine to Islamic Egypt: Religion, Identity and Politics after the Arab Conquest. London/New York: I.B. Tauris, 2014.

Morimoto, Kosei. The Fiscal Administration of Egypt in the Early Islamic Period. Kyoto:

Dohosha, 1981.

P.Cair.Arab. III = ed. A. Grohmann, Arabic Papyri in the Egyptian Library. Cairo: 19341962.

Severus of El Ashmunein (Hermopolis), History of the Patriarchs of the Coptic Church of Alexandria. Volume 4: Menas I to Joseph (849), Arabic text edited, translated, and annotated by B. Evetts, Patrologia Orientalis 10 (1910): 359-551.

Sijpesteijn, Petra M. “Arabic Papyri and Islamic Egypt.” In The Oxford Handbook of Papyrology, edited by R. S. Bagnall, 452-472. Oxford: Oxford University Press, 2009.

Sijpesteijn, Petra M. Shaping a Muslim State: The World of a Mid-Eighth-Century Egyptian Official. Oxford: Oxford University Press, 2013.

Sijpesteijn, Petra M. “Seals and Papyri from Early Islamic Egypt.” In Seals and Sealing Practices in the Near East. Developments in Administration and Magic from Prehistory to the Islamic Period. Proceedings of an International Workshop at the Netherlands-Flemish Institute in Cairo on December 2-3, 2009.” Edited by I. Regulski, K. Duistermaat and P. Verkinderen. Leuven, Peeters: 2012.

Simonsohn. Uriel. A Common Justice: The Legal Allegiances of Christians and Jews under Early Islam. Philadelphia: University of Pennsylvania Press, 2011.

al-Ṭabarī (d. 310/923), Muḥammad ibn Jarīr. Tārīkh al-rusul wa-l-mulūk. Edited by Michael J. de Goeje et al. 3 vols. Leiden: Brill, 1879-1901. 
This is the authors version of "Delegation of Judicial Power in Abbasid Egypt", in Berkel M.L.M. van, Buskens L.P.H.M., Sijpesteijn P.M. (eds.), Legal Documents as Sources for the History of Muslim Societies: Studies in Honour of Rudolph Peters, Leiden: Brill, 2017.

Please cite from the published version only, DOI: 10.1163/9789004343733_005

Tillier, Mathieu. “Deux papyrus judiciaires de Fusțāṭ (IIe /VIIIe siècle).” Chronique d'Egypte 89 (2014): 412-445.

Tillier, Mathieu. “Du pagarque au cadi : ruptures et continuités dans l’administration judiciaire de la Haute-Égypte (Ier-IIIe/Vie-IXe siècle).” Médiévales 64 (2013): 19-36.

Tillier, Mathieu. Histoire des Cadis Égyptiens Ahbār quḍ̄t Mișr. Cairo: IFAO, 2012.

Tillier, Mathieu. “Les “premiers” cadis de Fustat et les dynamiques régionales de l'innovation judiciaire (750-833).” Annales Islamologiques 45 (2011): 213-242.

Tillier, Mathieu. "The Qāḍ̄is of Fustat-Miṣr under the Ṭūlūnids and the Ikhshīdids: The Judiciary and the Egyptian Autonomy.” Journal of the American Oriental Society 131, no. 2 (2011): 207-222.

Tillier, Mathieu. "Scribes et enquêteurs : note sur le personnel judiciaire en Égypte aux quatre premiers siècles de l'hégire.” Journal of the Social and Economic History of the Orient 54 (2011): 370-404.

Tillier, Mathieu. Les cadis d'Iraq et l'État abbasside (132/750-334/945). Damascus: Presses de l’Ifpo, 2009.

Tillier, Mathieu. " $Q \bar{a} d \bar{l} \bar{l}$-s and the Political Use of the Mazālim Jurisidiction under the 'Abbāsids." In Public Violence in Islamic Societies: Power, Discipline and the Construction of the Public Sphere, $7^{\text {th }}-18^{\text {th }}$ Centuries CE, edited by C. Lange, and M. Fierro, 42-66. Edinburgh: Edinburgh University Press, 2009.

Tillier, Mathieu. Vies des cadis de Miṣr 237/851-366/976. Cairo: Institut français d’archéologie orientale, 2002. 